\title{
Reflections-Shaping Water Policy: What Does Economics Have to Offer?
}

\author{
Frank J. Convery*
}

\section{Introduction}

In Europe, water management is known as the second oldest profession, going back over two thousand years, to the time of the Roman Empire. In the film Life of Brian, a plotter in the People's Front for Judea makes the point: "Apart from the sanitation, medicine, education, wine, public order, irrigation, roads, the fresh water system and public health, what have the Romans ever done for us?"

This raises the question: Given the world's long track record with water management, how has economics contributed to water policy in the past, and how can it help us manage our water resources today and in the future?

In this "Reflections" column, I highlight some of the key contributions economists have made to the literature that seem especially relevant for informing water policy choices, and I offer some lessons for policymakers. My interest in this issue has been heightened by the fact that Ireland is radically changing its water policy $^{1}$ and the European Union is also revisiting its water policy. ${ }^{2}$ These and other emerging policy contexts present an opportunity to apply whatever our profession has to offer. Thus this column is directed at those involved in policymaking everywhere who have some responsibility for water policy and are interested in understanding what economics can do for them. This group, which I refer to as "the policymakers," includes politicians, public servants, advisers, resource managers, water enterprises, consumer interests (including farmers, households, industry, and commerce), environmental groups that tend to speak for the broader ecosystem values, and all the government departments and

*Senior Fellow, UCD Earth Institute, University College Dublin, Belfield, Dublin 4, Ireland. Telephone: +353(0)1-716-2672; e-mail: frank.convery@ucd.ie.

In terms of its coherence and clarity, this paper has benefited hugely from the editing support and advice of Suzanne Leonard, for which I am very grateful. The usual disclaimer applies.

\footnotetext{
1"You never want a serious crisis to go to waste," Rahm Emanuel, President Barack Obama's former chief of staff, made this observation in a speech at a Wall Street Journal conference in November 2008. It is now finding expression in Ireland, where a condition of accessing bailout funds is the implementation of a water pricing scheme.

${ }^{2}$ Guidelines for the application of economics are provided in European Commission (2002).
}

Review of Environmental Economics and Policy, volume 7, issue 1, winter 2013, pp. 156-174 doi:10.1093/reep/res017

(C) The Author 2013. Published by Oxford University Press on behalf of the Association of Environmental and Resource Economists. All rights reserved. For Permissions, please email: journals.permissions@oup.com 
agencies that have some stake in how water is managed. Because this column is aimed in particular at assisting these policymakers, as in my previous "Reflections" on energy efficiency (Convery 2011), I direct much of my discussion, especially the lessons for policy, to "you," the reader as policymaker.

In writing this column, I have benefited considerably from two articles by Sheila Olmstead, previously published in this journal, on the economics of water scarcity (Olmstead 2010a) and the economics of water quality (Olmstead 2010b). ${ }^{3}$ My goal is to include some literature that Olmstead did not address, provide more historical context, and focus explicitly on the needs of those in the policy process.

There are two big ideas that economists can offer to you as policymaker: (1) benefit-cost analysis, and (2) water pricing and the creation of water markets. With this in mind, the next section outlines how the benefit-cost analysis literature, as applied to water supply, can be helpful to the policymaker. Next I examine the issue of valuing the nonmarket benefits of water. This is followed by commentaries on some of the literature relating to water pricing and the creation of water markets. Each discussion ends with a summary of "Lessons for Policymakers." I conclude with a brief summary of how policymakers can use the tools of economics to better manage water resources.

A general lesson for policymakers that emerges from the literature is the need to support independent research focused on policy choices. Where conflict between competing users is inevitable, independent research can be valuable, especially if it is focused on developing evidence using a rigorous and well-respected analytical framework. It can also be valuable in litigation and court proceedings. Anchoring your case in independently validated evidence increases the prospects of prevailing. In this context, it is also important that the research be rooted in a rigorous theoretical framework, which helps ensure credibility and consistency. When commissioning independent research, give equal emphasis to sectors other than the residential sector; the literature has been heavily biased toward the latter.

Another strand emerging in the literature is the link between water policy and climate policy, which focuses on the argument that climate change is likely to increase the intensity and variability of rainfall in many parts of the world, implying heavier rainfall, more flooding, and more frequent dry spells and droughts. The case is made in general (see, e.g., Bates et al. 2008) and in specific areas of the world where rainfall is a key to economic activity (see Barnett et al. 2008 for an examination of the implications of climate change for California). In its study of the impacts of increasing water supply through the use of highly carbon-intensive desalination plants, the economics team of the Israel Climate Change Information Center (2011) argues that it is important to "Change the focus from managing water supply to prioritising and managing water demand. In contrast to Israel's current policy for water resources, the efforts should maximise the improvement of water supply efficiency, water recycling, prevention of water losses and the improvement of the water demand management before investing in desalination plants that carry high external costs." Acting on these recommendations will improve both economic efficiency and conservation of water.

${ }^{3}$ For a comprehensive overview of global trends in water quantity and quality, see Organization for Economic Co-operation and Development (OECD) (2012) and the World Water Assessment Program (2009). 


\section{Benefit-Cost Analysis and Water Supply}

Where water is scarce, there is often bad behavior. But water scarcity can also be the basis for great films, characterized by neurosis, greed, betrayal, murder, incest, and suicide. For example, in Europe, Jean de Florette and its sequel Manon des Sources tell the tragic story of a battle for access to water at the farm level. In the United States, Chinatown is based on the historical disputes over land and water rights that raged in southern California during the 1910s and 1920s. In this section I discuss the history of benefit-cost analysis, focusing on market benefits and costs, and identify the resulting lessons for policymakers.

\section{History of Benefit-Cost Analysis}

In a sense, the history of water economics in the United States was born out of conflict. Griffin (2012) and Kneese (2000) show how the drive to provide navigation, control floods, irrigate the West, and provide hydroelectricity resulted in pressure to undertake huge federally funded capital projects. Moreover, because the American taxpayer was being asked to contribute all or a substantial portion of the funding for these projects, there was an effort at the federal government level to determine whether and to what extent benefits exceeded costs. This was formalized by statute in the Flood Control Act of 1936, which established the welfare economics feasibility test that the benefits "to whomsoever they may accrue must exceed the costs." This legal requirement set the stage for battles between a loose alliance of academic economists (who used water projects as a test bed for the formalization of applied welfare economics) and presidents (especially their budget directors, who were responsible for budget coherence) on the one side, and project promoters and their regionally oriented political and sectoral allies (whose interest was in passing the welfare test, regardless of how this was achieved) on the other.

Robert Haveman (1972) looked back at the benefits and costs of a range of major public investments in water in the United States that focused on flood control, hydroelectricity, and navigation. Haveman's work was rooted in applied welfare economics, which emphasizes efficiency benefits and costs. The analysis was simple and elegant in its execution, and the conclusions were powerful in their policy implications, albeit modestly expressed: "While the results of this case study are based on a number of judgmental assumptions, they do demonstrate that the realized direct benefits of the projects fell substantially short of the ex-ante benefits estimates."

The work by Haveman (1972) was the inspiration for an ex post analysis I coauthored (Bruton and Convery 1982) of nationally funded flood control projects implemented in Ireland between 1950 and 1981. We found that, whereas the earlier projects yielded substantial net benefits, by 1977 diminishing returns had set in. Thus more recent investments did not yield net benefits, and the program was phased out over the coming decade. ${ }^{4}$ Although there were also substantial environmental costs caused by drainage-loss of habitat, visual degradation, damage to fisheries, and so on-we did not need to evaluate these impacts, since the commercial benefits of the most recent projects did not cover the financial costs.

${ }^{4}$ It is easy to exaggerate cause and effect. One recalls the observation by the British-born Canadian humorist Stephen Leacock: "When I state that my lectures were followed almost immediately by the Union of South Africa, the banana riots in Trinidad and the Turco-Italian war, I think the reader can form some opinion of their importance." 
Olmstead (2010a) provides a good summary of the literature relating to water supply in developing countries and notes that where households are not connected to piped water, they "may pay very high prices for water from the informal sector" (p. 3). But in a separate coauthored article, Akram and Olmstead (2009) suggest that quality may be more valued than quantity. More specifically, households in developing countries may be willing to pay less for improvements in service quality (reducing variability or interruptions in the water delivery schedule) than for improvements in drinking water quality (Akram and Olmstead 2009).

In a study for the World Health Organization, Prüss-Üstün et al. (2008) estimated the costs and benefits of achieving the United Nation's Millennium Development Goal of reducing by half the proportion of people without sustainable access to safe drinking water and basic sanitation (see www.undp.org/mdg/goal7.shtml). The estimated benefit-cost ratio was 7:1. Table 1 provides a summary of the estimated benefits.

\section{Lessons for Policymakers}

The literature and experience concerning the use of benefit-cost analysis for the management of water supply offers some important lessons for policymakers.

(1) Challenge your team to find the least-cost way to achieve a particular objective. This is called being "cost effective." You will often be faced with a situation in which you are not asked whether something should be done but rather what is the least-cost way to achieve it.

(2) Benefit-cost analysis is a powerful tool for "selling" specific policy interventions. You should use this analytical tool both to make the case for interventions that yield substantial net benefits and to argue against interventions that do not. You need to be proactive, or others will fill the vacuum.

(3) For new investments proposed to expand water supply, irrigation, power generation, or enhance flood control, estimate the capital and operating costs and value the benefits for which market proxies can be credibly estimated (e.g., time savings, improved productivity, increased power supply, farm output, reduced flood losses). This market valuation should precede addressing the more difficult challenge of developing credible estimates of the value of nonmarket benefits and costs (discussed in the next section). This sequencing of the analysis is useful because sometimes the decision about a proposed project can be made based solely on the valuation of its so-called commercial (i.e., market) benefits.

(4) Legislate requirements for benefit-cost analysis, and facilitate ex-post work. Implement a regulation or statute that requires proposed projects be justified on the basis of costs and benefits. Such a legislative mandate is important because it institutionalizes an approach to evaluating projects whereby evidence must be marshaled to justify proposals. It also provides both an analytical framework and a body of evidence that enables scholars to look back and judge whether past investments have been effective. Although "never look back" may be a popular philosophy among many supporters of new projects, an examination of history (i.e., ex-post analysis) can yield important lessons for the future. 
Table I Estimated benefits of meeting millennium development goals for water

\begin{tabular}{lcc}
\hline Category of benefit & Breakdown of benefits & $\begin{array}{c}\text { Monetised benefits } \\
\text { (billions of USD) } \\
\text { per year }\end{array}$ \\
\hline $\begin{array}{l}\text { Time savings from improved } \\
\text { water and sanitation services }\end{array}$ & $\begin{array}{c}20 \text { billion working days per year } \\
\text { due to savings from walking or queuing } \\
\text { Productivity savings }\end{array}$ & 63 \\
$\begin{array}{l}\text { Working, school, children under 5; } \\
\text { water borne diseases responsible for } \\
\text { 30\% of deaths of children under 5 }\end{array}$ & 9.9 \\
Health care savings & $\begin{array}{l}\text { Agencies and individuals - reduced water } \\
\text { borne diseases (diarrhoea, malaria, }\end{array}$ & 7.34 \\
dengue fever) & \\
Deaths averted & Discounted future earnings & 3.6 \\
Total & & 84 \\
\hline
\end{tabular}

Source: OECD $(2012,55)$.

(5) Broaden the canvas of choice. The early benefit-cost work on water addressed only binary choices, a yes or no decision on the project as proposed. Yet there are, in fact, many choices to consider as to the scale, character, and content of a project. There are also nonstructural choices. Griffin $(2012)$ quotes Boulding $(1964,88)$ to make this point: "The truth is that what we call 'flood control' means the eradication of disasters every 10 years or so at the cost of a really big disaster every 50 or 100 years in any given floodplain... This is largely because we have regarded flood control as a problem in engineering rather than sociology."

Ensuring that related alternatives are addressed is especially important in situations where water and financial resources are scarce. Olmstead (2010a, 4) quotes a study by Whittington et al. (1993) in which twelve hundred households in Kumasi, Ghana, were interviewed concerning their willingness to pay (WTP) for sewage treatment. They found that WTP for conventional treatment was the same as for improved ventilated latrines. "Since on-site sanitation is much cheaper than conventional sewage treatment infrastructure, the subsidies required to support improved latrines for all local households are markedly smaller than those that would be required to support conventional treatment."

(6) Match the analytical framework to the realities of decision making. There is a compelling logic to using river basins as the unit of space for managing water resources: they capture most of the physical and biological interdependencies and, in theory, allow the net return to society (on both the infrastructural investment and resource management) to be maximized. Unfortunately, river basins rarely match decision makers' jurisdictions. Your first responsibility as a policymaker or as a member of the policymaking team is to help decision makers, whatever their jurisdiction, but you also have a responsibility to encourage those in the policy process to adopt a river basin perspective. In practice, river basins are generally not used as the unit for water management decisions, probably because of the lack of fit between the geography of river basins and political authority. This disconnect is highlighted by the OECD (2012), which conducted a survey to assess the extent to which the river basin perspective was used for decision making. 
Table 2 Missions of river basin organizations in OECD countries

\section{Function}

No. of respondents (out of a total respondent pool of 17)

Planning, data collection, policy harmonisation, monitoring

Allocation of uses, pollution prevention, co-ordination

Financing, regulation

Infrastructure

Other

Source: OECD (2012, I2I).

As shown in Table 2, more than half of the seventeen respondent countries use river basins for planning, data collection, policy harmonization, and monitoring, but only about a third use them for finance, regulation, and infrastructure. Thus the reality diverges considerably from the ideal. Unfortunately, although both the scope and the scale of water supply and wastewater treatment projects are likely to be important determinants of their costs and benefits, I was not able to find substantive empirical work that either supported or contradicted the proposition that scale is important. Thus the literature does not provide guidance concerning the economics of scale and scope.

\section{Valuing Nonmarket Benefits}

The early work on benefit-cost analysis focused on the value of water in uses related directly to economic activity. However, it is clear that many values associated with water (and nature in general) are not directly linked to markets. In fact, in terms of papers published, the most rapidly expanding area of environmental economics appears to be characterizing these nonmarket values and giving them some empirical expression.

Sigfried von Ciriacy-Wantrup, who spent his academic career at the Department of Agricultural and Resource Economics, University of California, Berkeley, was the first to suggest that "appropriately constructed interviews" may be capable of obtaining information about people's preferences for goods not ordinarily priced in the market (Ciriacy-Wantrup 1947). Since then, the contingent valuation (CV) method has become the most widely used approach for obtaining WTP values for a variety of environmental and other nonmarket public goods. UC Berkeley "incubated" the CV field and nurtured it over many years. An early shot across the bows of CV practitioners was provided by Kahneman and Ketch (1992) who noted that how questions were embedded, the order in which they were asked, etc., would significantly influence responses. Michael Hanemann produced seminal articles on CV (Hanemann 1984, 1994), which are among the most cited articles in environmental economics. Richard Carson, also a leader in the field, earned his PhD at UC Berkeley and is now at UC San Diego. In his comprehensive bibliography, Carson (2011) records 7,500 contingent valuation studies undertaken in 130 countries. Thus what began at UC Berkeley fifty years ago has become a global phenomenon. History has shown that these contingent values get converted into cash when issues of legal liability arise. 


\section{The Law as a Driver}

Based on his observation of policy in action in the United States, Keynes argued that "The Mayflower, when she sailed from Plymouth, must have been entirely filled with lawyers." Indeed, legal action has been a key driver for nonmarket valuation in the United States. As many readers may recall, on March 24, 1989, the Exxon Valdez oil tanker struck Bligh reef in Alaska's Prince William Sound, spilling large amounts of oil and causing major environmental destruction (the area is habitat for salmon, sea otter, seals, and seabirds), which became the focus of litigation. Carson $(2011,12)$ makes the point: "By far the greatest stimulus to the current CV debate was the enactment of US laws that allowed for the recovery of monetary damages for injuries to natural resources. The focus point was the Exxon Valdez oil spill in which the government's case was largely based upon a monetary case for loss of passive use.... Exxon paid the government one billion dollars in natural resource damages, and spent two billion dollars on response and restoration activities."

Input from Nobel laureates adds both intellectual and legal credibility to any research effort. Following the Exxon Valdez incident, in 1993 the US National Oceanic and Atmospheric Administration (NOAA) commissioned a Blue Ribbon Panel to answer the question "Is CV a valid method for determining the lost economic value from natural resource damages?" The panel featured two Nobel Prize winners (Kenneth Arrow and Robert Solow) and heard the testimony of some of the most prominent advocates and critics of the CV method. The panel concluded that the CV method can produce reliable estimates of the lost value from natural resource damages provided researchers meet a high standard of proof, and they provided guidance as to the characteristics that such studies should contain (Arrow et al. 1993).

Similar guidance has been provided for researchers in Europe. Since 2000, the Water Framework Directive has been a driver for economic analysis of water policy in the European Union, calling for full cost recovery by users of water and the use of economic analysis in its management. ${ }^{5}$

\section{Benefits Transfer}

To what extent can values derived from one study be applied in other contexts? This is an important question, especially because studies that meet the standards set by the NOAA panel are expensive and time consuming to undertake, and the costs can be reduced dramatically if the values can indeed be transferred. Unfortunately, the literature on the feasibility of benefits transfer is not reassuring. For example, a very fine recent paper on whether benefits transfer works in the context of water quality ${ }^{6}$ concludes (Bateman et al. 2011, 384), "Our study findings suggest some broad and pragmatic guidelines for the future application of value transfers. Essentially we conclude that, where transfers involve broadly similar provision changes of similar goods across similar contexts, then simple mean value transfers are likely to give defensible welfare estimates... The different operation (or even omission) of contextual factors between sites is liable to generate substantial transfer errors."

\footnotetext{
${ }^{5}$ See http://ec.europa.eu/environment/water/water-framework/pdf/water_note5_economics.pdf for a detailed description and Brower (2008) and Hanley, Wright, and Alvarez-Farizo (2006) for analysis of this approach. ${ }^{6}$ It also illustrates the transnational nature of much contemporary work in this field, with authors from Belgium, Denmark, Italy, Lithuania, the Netherlands, Norway, and the United Kingdom.
} 


\section{Lessons for Policymakers}

Economic research on nonmarket valuation as well as experience with litigation provide some useful lessons for policymakers:

(1) Understand the relationship between regulation and the minimum flow needed to deliver ecosystem services (e.g., habitat for plants and animals, biodiversity, water storage for nature, and flood mitigation). In some jurisdictions, such regulation will be handed down as an absolute regulatory requirement, not subject to economic valuation or discussion. In others, there will be scope for more or less regulation. Where there is flexibility, then encouraging collaboration between economists with expertise in CV and scientists who understand the production functions that yield such ecosystem services will help inform the debate about how much regulation to provide.

(2) Where contingent valuation is likely to be useful, examine the potential of using values derived from previous studies before undertaking new studies. As noted earlier, this will be much less expensive than doing original work, but it will only be credible when the conditions are very similar, which is often unlikely.

(3) Where original work is called for, use best practices. The NOAA guidelines are the place to start, bearing in mind that the field is constantly evolving (see, e.g., Atkinson, Bateman, and Mourato 2012) and techniques are improving. This will give you some protection if there is litigation, which is becoming increasingly common.

\section{Water Pricing}

Prices reflect scarcity. Where there is scarcity, but no price, or a price so low that nonprice rationing is necessary, the market is failing. And where markets fail, a first choice for most economists is to introduce a price that clears the market and ensures that the scarcity value is reflected in the choices consumers make. In regard to water, history, geography, and often legal and political support for first users inhibit or in some cases completely prevent the emergence of a price that reflects scarcity. Market failure is compounded by policy failure, which is often associated with issues concerning property rights. Riparian rights, whereby all landowners whose property adjoins a body of water have the right to make "reasonable" use of it, and the right to water cannot be transferred other than with the transfer of the adjoining land, work well when the supply of water is large relative to consumption, and where users at a distance from such water cannot benefit significantly from access to this resource. But in situations where nonadjoining landowners could benefit significantly from access to water, there can be large welfare losses if such access is not facilitated. Some societies develop systems for providing access to nonadjoining landowners, typified by the "prior appropriations" doctrine, which provides the right to divert a specified quantity of water, often with a specific seniority relative to other users.

Although such mechanisms help overcome the initial inefficiencies inherent in a system that precludes such users, they create new inefficiencies in that new users - such as new urban settlements, new technologies, and new cropping systems — can be locked out. This is complicated in some situations by property rights ambiguities, where ownership by law (de jure) may ultimately be vested in the state, but in practice (de facto) is held by the incumbent users. 
Hanemann, Lambe, and Farber $(2011,52)$ address this theme in the context of appropriation rights in California: "The current appropriative system in California places the risk of drought on junior users, while more senior users are protected from risk. That is, during times of drought senior users receive their entire allocation while junior users receive no water at all. (At least this is true in theory, but given the lack of clarity about appropriative rights, the senior user may actually own only the right to a lawsuit against allegedly junior users.)"

Prices that reflect scarcity can be introduced either by government asserting de facto ownership and charging for use on behalf of the public, or by facilitating the creation of property rights that allow water to be separated from land and bought and sold; the price ensuing from such transactions corrects in part for market failure.

\section{Introduction to the Pigouvian Approach}

The concept of government charging for water is associated with Pigou (1952, Part 1, Chapter 2, "Desires and Satisfactions," para 1.2.7) ${ }^{7}$ : "It is the clear duty of government which is the trustee for unborn generations as well as for its present citizens, to watch over, and if need be, by legislative enactment, to defend, the exhaustible natural resources of the country from rash and reckless spoliation."

There is a substantial and convincing literature to the effect that using price rather than regulation to reflect the scarcity value of the environment yields a given level of environmental quality at a lower cost and encourages innovation. ${ }^{8}$ The best analogs of the literature on the management of water quantity are provided by Olmstead and Stavins (2009), who focus on urban water and draw heavily on the limited literature that addresses this issue in the United States. Relying on statistical studies, they conclude that there are indeed potential economic gains from a shift from technology standards and rationing to market-based approaches, and that pricing also has advantages over regulation when it comes to monitoring and enforcement. The gains come from allowing households to respond to increased water prices in the manner of their choice, rather than installing a mandated technology or reducing specified uses.

Long-run marginal cost (LRMC) of supply reflects "the full economic costs of water supply-costs of transmission, treatment and distribution; some portion of the capital cost of current reservoirs and treatment systems, as well as future facilities necessitated by current patterns of use; and the opportunity cost of both the use and nonuse value of water for other potential uses" (Olmstead 2010b, 6). Because it is efficient for consumers to face the full marginal costs of each additional liter they consume, economists argue that this is what consumers should be charged. However, applying this charge will typically produce income that exceeds the cost of supply. Because the cost of new water supplies will typically be higher than the cost of current supplies, a LRMC policy will produce income that is higher than the (public or private) utility's current cost of supplying water. Thus the "first best" solution in this situation is to charge consumers the (higher) LRMC of supply and then return the surplus to them in the form of a lump sum. This keeps the price incentive fully intact. Although this solution is also fair, in that consumers get back any surplus revenues generated, it is not a

${ }^{7}$ Available at http://www.econlib.org/library/NPDBooks/Pigou/pgEW2.html.

${ }^{8}$ This is touched on later in the discussion of the responsiveness of water quality to price. 
popular policy. Olmstead and Stavins (2009) are perhaps guilty of understatement when they observe (p. 6) that "raising prices can be politically difficult." They go on to cite the experience in Tucson, Arizona: "After a 2-year drought in the late 1970s the city of Tucson Arizona was the first US city to adopt marginal cost water prices, which involved a substantial increase. One year later, the entire Tucson city council was voted out of office because of the water rate increases." This is why most jurisdictions do not follow the advice of economists in their pricing policies and governments typically pay a significant share of the investment and/or operating costs of providing water services (see Table 3 ).

It is notable that both France and Japan recover all of the operating costs from consumers. However, as shown in Table 4, there is considerable variation across countries in what households are charged for water (and sanitation) services.

\section{Issues of Fairness}

There are additional fairness issues concerning how (and at what price) water is allocated. Thobani $(1995,1)$ makes the case that allocation provided free or at low cost often discriminates

Table 3 Share (\%) of costs for water and sanitation services paid by governments and consumers (2008)

\begin{tabular}{lcccrr}
\hline Type of cost and share of funding & Spain & France & Canada & Japan & US \\
\hline $\begin{array}{l}\text { Investment costs } \\
\text { Government share }\end{array}$ & 70 & 50 & 75 & 100 & 70 \\
$\quad$ Consumer share & 30 & 50 & 25 & 0 & 30 \\
Operational costs & & & & & \\
$\quad$ Government share & 50 & 0 & $50-70$ & 0 & 50 \\
$\quad$ Consumer share & 50 & 100 & $30-50$ & 100 & 50 \\
\hline
\end{tabular}

Source: OECD $(2012,84)$.

Table 4 Unit price to households for water supply and sanitation services in 2008 , in US\$ per $M^{3}$

\begin{tabular}{lccc}
\hline Country & Water supply & Sanitation & Total \\
\hline New Zealand & 0.7 & 1.2 & 1.98 \\
Italy & 0.8 & 0.7 & 1.45 \\
Spain & 0.9 & 0.5 & 1.92 \\
Finland & 1.7 & 2.7 & 4.41 \\
England and Wales & 1.8 & 2.0 & 3.82 \\
France & 1.9 & 2.0 & 3.74 \\
Germany & 2.5 & $\mathrm{NA}$ & $\mathrm{NA}$ \\
Scotland & 2.6 & 3.1 & 5.7 \\
Denmark & $\mathrm{NA}$ & $\mathrm{NA}$ & 6.7 \\
\hline
\end{tabular}

Notes: Unit price includes relevant volumetric charges and recurrent fixed charges, not including connection or other one-off charges. Differences between totals and components are due to a lack of availability of separate data. Charges for sanitation are typically higher than for water supply. Conversion factor: Acre foot $=1,233.482 \mathrm{M}^{3}$, or 1.233482 million liters. NA, not applicable.

Source: OECD $(2010,45)$. 
against the poor in developing countries:

These systems have tended to favour the relatively wealthy, who manage to get easier access to water rights, which are usually obtained without charge and for whose use farmers pay only a small fraction of the costs of building and operating the associated irrigation infrastructure. Similarly, while the better off residents in many cities in developing countries enjoy access to cheap, municipally supplied water, many of the poor in the same cities must resort to very expensive private water truckers to meet daily needs.

Related to the difficulty of getting users to pay the full LRMC is the fact that water is an essential good, and it can comprise a significant share of the net disposable income of poor people (see Table 5). In Poland, for example, the poorest 10 percent spend almost 8 percent of their disposable income on water and sanitation services.

\section{Responsiveness of Water Consumption to Price}

The key findings of Olmstead's survey of the literature (Olmstead 2010b) on the price elasticity of water consumption (percentage change in consumption to a 1 percent change in price), which focuses on residential use, are summarized in Table 6.

Table 5 Payments for water supply and sanitation services as \% of average net disposable income, 2008

\begin{tabular}{lcc}
\hline Country & Average & Poorest $\mathbf{0 \%}$ \\
\hline Italy & 0.3 & 1.4 \\
Spain & 0.4 & 2.2 \\
New Zealand & 0.5 & 1.6 \\
Sweden & 0.5 & 1.8 \\
England and Wales & 0.6 & 2.0 \\
Scotland & 0.9 & 2.8 \\
Denmark & 0.9 & 2.5 \\
Poland & 1.2 & 7.9 \\
\hline
\end{tabular}

Source: OECD $(2010,74)$.

Table 6 Price elasticity estimates for water (residential, agriculture, industry)

\begin{tabular}{|c|c|c|}
\hline Sector & Price elasticities & Comments \\
\hline Residential & $\begin{array}{l}\text { Meta analysis drawing on } 124 \text { estimates. Average: }-0.5 \text { I } \\
\text { Meta analysis drawing on } 300 \text { estimates. Average: }-0.4 \text { I }\end{array}$ & The focus of most studies \\
\hline Industrial use & $\begin{array}{l}\text { Wide range: from }-0.15 \text { to }-0.98 \text { (chemical industry) } \\
\text { French study: from }-0.10 \text { to } 0.79\end{array}$ & Vary by industry \\
\hline Agriculture & $\begin{array}{l}\text { Meta-analysis drawing on } 24 \text { estimates in US. } \\
\text { Average: }-0.48\end{array}$ & $\begin{array}{l}\text { Estimates vary widely and } \\
\text { often approach zero. } \\
\text { Estimates higher in regions } \\
\text { where water is scarce and } \\
\text { prices are higher }\end{array}$ \\
\hline
\end{tabular}




\section{Responsiveness of Water Quality to Price}

Kneese and Bower (1968) provided the empirical ballast for the proposition that charging polluters based on the environmental damage they cause imposes much lower total costs than controlling such emissions solely through regulation (command and control). For a Europhile such as myself, there was particular satisfaction in the fact that they used case studies from England, France, and (especially) West Germany to support their case. In addition to offering economic efficiency arguments, they addressed in some detail the engineering aspects of wastes and their treatment (Bower had engineering training), as well as the institutional arrangements that are so critical in determining whether economic efficiency is feasible. ${ }^{9}$

\section{Second-Best Pricing: Increasing Block Prices for Residential Users}

The second-best solution to water pricing would be to use increasing block prices (IBPs), where prices rise in steps as volume consumed rises per unit of time. In their study of household water demand, Olmstead, Hanemann, and Stavins $(2005,7)$ observe,

Urban residential water service pricing typically takes one of three forms: (1) a uniform marginal price; (2) increasing block prices; or (3) decreasing block prices. Each of these price structures is typically accompanied by a fixed water service fee. Under constant or uniform rates, households pay a single volumetric marginal price at all levels of consumption. Increasing block structures charge higher marginal prices for higher quantities consumed, resulting in a water supply function that resembles a staircase ascending from left to right.

They note that increasing block pricing comprises a growing share of residential pricing in the United States, rising from 4 percent of the total in 1982 to about a third by 2000. Following on early work by Hanemann (1997), Olmstead et al. (2005) analyzed consumption and price data for 1,082 households in eleven urban areas in the United States and Canada and concluded that consumers were more responsive to price changes than flat charges. In particular, they found that "For households facing increasing block prices (IBPs) only, we obtain a simulated price elasticity of approximately -0.64 . When we estimate a panel random-effects model for households facing uniform marginal prices only, we obtain an elasticity estimate of -0.33 , and the effect is statistically insignificant, even with about 400 households in this group" (p. 20).

\section{Income Elasticity}

Information on how responsive water consumption is to income is an important complement to information on prices and price elasticity. This relationship is captured in income elasticity, the percentage change in water consumed resulting from a 1 percent change in real (net of inflation) income.

\footnotetext{
${ }^{9}$ For example, in examining the success of water quality management in the Ruhr valley in Germany, Kneese pointed to the work of Genossenschaften, cooperatives run by industry and local government with the lightest of controls from central government.
} 
Olmstead et al. (2005) find an income elasticity among households in the United States that is lower than in previous studies, with most earlier estimates falling in the range of 0.2 to 0.6 (Hanemann 1997).

\section{Lessons for Policymakers}

There are four lessons to take away from this review of the literature on water pricing:

(1) Keep making the case that prices are important. Prices stimulate efficient use by allowing consumers to make their own choices, encouraging conservation and innovation, allowing investment in expensive new supplies to be deferred, and generating income that facilitates effective management and investment.

(2) Consider the use of randomized control trials (RTCs) to inform policy choices, including water prices. The RTC approach compares outcomes for a control group (untreated-e.g., free water) with outcomes for another group that is treated (e.g., they face IBPs for water). This approach has been widely applied to test the efficacy of pharmaceuticals and has been used more recently to assess policy outcomes in developing countries. In particular, Esther Duflo of MIT's Poverty Action Lab has pioneered the application of this approach to assess choices for the poor. ${ }^{10}$ This approach has been greeted by some with a degree of hubris. For example, Deaton $(2009,25)$ quotes an editorial in the British Medical Journal: "Britain has given the world Shakespeare, Newtonian physics, the theory of evolution, and the randomised trial." He goes on to assess the strengths and weaknesses of the approach: "What we can observe in the data is the difference between the average outcome in the treatments and the average outcome in the controls." The main weakness he identifies is that the approach tells us nothing about why outcomes are achieved (or not achieved). Policies that are implemented without exploring the "why" are likely to result in disappointment. Thus if you decide to apply the RTC approach to water policy, it is important to simultaneously explore the "why."

(3) Estimate the long-run marginal costs of supply for each sector (household, industry, etc.), and identify who is benefiting from subsidies. This gives you a basis for educating everyone on what water actually costs, who is benefiting from subsidies, and to what extent. The LRMC of supply provides you with the information needed to get as close as you can-bearing in mind the political constraints — to charging this price to the relevant users. ${ }^{11}$

(4) Explicitly address the fairness issue. You face a paradox: although richer people consume more water than poorer people, for the poorest, the water bill can be a significant share of total disposable income. Direct cash transfers to the water poor, analogous to transfers to the fuel poor, is one mechanism for addressing this issue. Another option is to use increasing block pricing, whereby a minimum amount of water is provided at a very low price.

\footnotetext{
${ }^{10}$ See Duflo and Kremer (2003) for the rationale and a summary of this approach.

${ }^{11}$ The issue of achieving transfers between sectors is addressed later.
} 


\section{Creating Water Markets ${ }^{12}$}

Coase (1960) took issue with the Pigouvian approach and analysis. In contrast to relying on government-determined prices to allocate water, Coase proposed a more conservative approach that emphasizes the value of creating social arrangements whereby individuals or organizations would trade among themselves if the benefits of doing so exceeded the costs, concluding that (Coase 1960, 23), "It would clearly be desirable if the only actions performed were those in which what was gained was worth more than what was lost.... Furthermore we have to take into account the costs involved in operating the various social arrangements.... In devising and choosing between social arrangements we should have regard for the total effect."

By drawing attention to the costs and benefits of action or inaction, and the transaction costs, Coase (1960), in effect, made the case for facilitating interaction between the agents so that they would automatically find the least-cost outcome, independent of the assignment of property rights. This is the intellectual underpinning of emissions trading, as well as trading water between users and sectors. That is, by assigning effective property rights and facilitating trade, a market is created.

In terms of water markets, the Coasian view would be to reduce the transaction costs between the various users of the resource to the point where they could transact with each other directly and water would find its way to the user willing to pay the most for it.

\section{The California Water Bank}

The California Water Bank is one well-documented example of managing water resources by facilitating the creation of a water market (Howitt 1994). The water bank was established in 1991 and aimed at facilitating the transfer of water from low value uses (mainly farming) to higher value uses (mainly urban). It was created after several years of drought, and operated by the state Department of Water Resources. Purchasers of water (mainly urban users) paid a fixed charge of \$140 at the Sacramento Delta, with most of the difference between the purchase price and the sale price to end users being used to pay for carriage water (transport and related costs). At this purchase price, plus the transportation cost from the Delta, the Bank sold 488 million $\mathrm{M}^{3}$ of water. Three quarters of the water was sold to urban agencies, at a cost (including transportation) of over $\$ 185 / \mathrm{M}^{3}$. The water was purchased mainly from farmers: 50 percent from irrigation water that they would otherwise have consumed, and 33 percent in the form of exchanging their surface water rights for groundwater rights and selling the surface water to the bank. This transfer of water from lower to higher value uses resulted in estimated gains to the economy of \$106 million in net income and more than 3,500 jobs. Hanemann et al. (2012) acknowledge the program's achievements, but also note some caveats (pp. 29-30):

While the Water Bank purchases were useful adaptations to a situation of shortage, they were essentially short-run in nature. There is no evidence, for example, that sellers would have been willing to fallow their land for multiple years in a row.... To the extent that, with climate change, water shortages become a frequent occurrence in California, these temporary adaptations may not be a fully adequate solution. The use of pumped groundwater to substitute for surface water transferred

\footnotetext{
${ }^{12}$ See http://www.sscnet.ucla.edu/ssc/labs/cameron/nrs98/wtrmkt97.htm for a list of studies on water markets.
} 
to the Water Bank reinforces the tendency to overdraft groundwater that already exists among surface water users in California.

Gray (2008) also acknowledges the market's achievements in providing supplemental supplies at times of drought but is concerned that third parties were not well represented (pp. 94-95): "The state must establish a comprehensive and consistent process for the consideration of third party interests that are potentially affected by transfers... The market alone will not represent all the relevant interests."

\section{Water Markets in the US West and Australia}

Grafton et al. (2011) provide a comprehensive ex-post analysis of water markets in the US West (Arizona, California, Colorado, Nevada, and Texas) and Australia's Murray-Darling basin (which includes the states of South Australia, New South Wales, Queensland, and Victoria). ${ }^{13}$ These are their key conclusions:

(-2) Quantities should be defined in terms of shares of available water rather than absolute quantities.

$(-1)$ Transaction costs, mainly those that could be triggered by legal action, need to be reduced to what is feasible, and carefully managed.

(0) Benefits are significant—for example, "Perennial crop farmers (in Australia) ... who irrigate orchards and vineyards... found during the millennium drought that their assigned seasonal allocations were less than expected ... Without the ability to purchase seasonal allocation of water during the worst years of the drought, many of their vineyards and orchards would have suffered major harm or died" (p. 13).

(1) Facilitating trade offers very large benefits for both farmers and urban dwellers, with the latter willing to pay up to 10 times the agricultural value of water.

\section{Water Markets in Chile}

Another well-documented example is the creation of water markets in Chile. Together, Bauer (1995), Briscoe, Salas, and Humberto (1998), Gazmuri (1992), and Hearn and Easter (1995) provide a comprehensive review of Chile's program and its achievements and limitations, which I summarize here:

- The separation of water rights from land rights in Chile's laws and constitution provides the fundamental basis for the implementation of a market-led approach.

- There is wide acceptance of the Dublin principles, which recognize the economic value of water and its social function. ${ }^{14}$

\footnotetext{
${ }^{13}$ Waye and Son (2010) and Pigram (1993) also examine the adoption of water markets in Australia.

${ }^{14}$ Four principles were agreed on in January 1992 at the International Conference on Water and the Environment in Dublin, Ireland: (1) Fresh water is a finite and vulnerable resource, essential to sustain life, development and the environment. (2) Water development and management should be based on a participatory approach, involving users, planners and policymakers at all levels. (3) Women play a central part in the provision, management, and safeguarding of water. (4) Water has an economic value in all its competing uses and should be recognized as an economic good.
} 
- The availability of appropriate technology is important. For the viability of markets for bulk water supply, the availability of technology to allow water to be diverted (provision of adjustable gates, measuring systems) is crucial. ${ }^{15}$

- Linking water allocation to land reform, and allocating water to those who are actually using it, provides legitimacy (and fairness) to the allocation process.

- The registration and assignment of other property rights is important.

- Institutions and low-cost mechanisms for conflict resolution are also important. The Water User Associations in Chile play a crucial role in managing the water owned by their members and in managing potential conflicts between them.

- Because water is essential, and its provision typically involves monopoly power on the part of the supplier, there is a need for a regulatory framework that provides positive incentives for the various stakeholders; the use of markets does not imply in any sense the abrogation of government responsibility for setting and implementing the appropriate regulatory context.

- Educating key interest groups and the public is essential, including allowing them to participate in decisions to help foster a sense of ownership of the process.

- The availability of funds and how they are dispersed have considerable bearing on effectiveness. The Water User Associations impose a levy on members, which is used to finance the operation of the water supply system. This flow of funds is crucial to the success of the program.

\section{Lessons for Policymakers}

The theory and experience with water markets offer four key lessons for policymakers.

(1) Make the case that facilitating trades within and between sectors can yield very large benefits. The evidence from the California Water Bank shows that both sellers (mainly farmers) and consumers (mainly cities) benefited. In Chile, farmers who had export opportunities in viticulture and other crops were able to expand rapidly.

(2) Recognize and meet the demanding preconditions that are necessary for water markets to succeed. These preconditions include separation of water rights from land rights, appropriate and enabling technology, fairness of initial water allocation, identification and registration of property rights, low-cost mechanisms for conflict resolution, effective regulation and education, and availability of finance to operate the system.

(3) Rely on intermediaries where appropriate. When price discovery is difficult and transaction costs are generally high, the use of a trusted intermediary such as the Water Resources Board in California can be very effective.

\footnotetext{
${ }^{15}$ In a number of river basins in Chile, there is a technological problem of fixed dividers making it difficult and expensive to reallocate water. Where the benefits of reallocation are large, as in the case of selling from agriculture to municipal users in the Elqui River basin, then it is worth making the investment. But frequently, the costs of technological modification are so large relative to the benefits of trading that the transactions do not take place. A systematic assessment of the costs and benefits of investing in technologies that would allow markets to flourish offers the most promising opportunity for extending the reach of markets.
} 
(4) Address potential impacts on third parties and other resources. The interests of those affected by, but not included in, the trading scheme need to be represented by the regulatory authority, for example, by setting minimum flows to meet environmental and ecosystem support functions, and by regulating the substitution of groundwater abstraction for surface water that is traded; if, for example, farmers sell their surface water to urban users, and replace this water by drilling and extracting groundwater, then policy needs to ensure that this latter activity does not impose significant costs on others.

\section{Conclusions}

This Reflections column has examined the extensive and evolving literature regarding the economics of water policy. This literature suggests that if applied appropriately, the tools of economics can help you avoid water-related investments that are economically inefficient and environmentally damaging. They can also help you to manage an increasingly scarce resource in ways that are both fair and efficient.

\section{References}

Akram, Agha Ali, and Sheila M. Olmstead. 2009. The value of household water service quality in Lahore, Pakistan: Working paper, School of Forestry and Environmental Studies, Yale University.

Arrow, Kenneth, Robert Solow, Paul R. Portney, Edward E. Leamer, Roy Radner, and Howard Schuman 1993. Report of the NOAA Panel on Contingent Valuation. http://www.darrp.noaa.gov/ library/pdf/crblue.pdf.

Atkinson, Giles, Ian Bateman, and Susana Mourato. 2012. Recent advances in the valuation of ecosystem services and biodiversity. Oxford Review of Economic Policy 28: 22-47.

Barnett, T. P., D. W. Pierce, H. G. Halliday, C. Bonfils, B. D. Santer, T. Das, G. Bala, A. W. Wood, T. Nozawa, A. A. Mirin, D. R. Caya, and M. D. Dettinger. 2008. Human-induced changes in the hydrology of the western United States. Science 319: 1080-83.

Bateman, I. J., R. Brouwer, S. Ferrini, M. Schaafsma, D. N. Barton, A. Dubgaard, B. Hasler, S. Hime, I. Liekens, S. Navrud, L. De Nocker, R. Ščeponavičiūte, and D. Semènienè. 2011. Making benefit transfers work: Deriving and testing principles for value transfers for similar and dissimilar sites using a case study of the non-market benefits of water quality improvements across Europe. Environmental and Resource Economics 50: 365-87.

Bates, B., Z. W. Kundzewicz, S. Wu, and J. Palutikof, eds. 2008. Climate change and water. Technical Paper of the Intergovernmental Panel on Climate Change. Geneva, Switzerland: IPCC Secretariat.

Bauer, Carl Jonathan. 1995. Against the current? Privatisation, markets, and the state of water rights, Chile, 1979-1993. Berkeley: University of California Press.

Boulding, Kenneth. 1964. The economist and the engineer: Economic dynamics of water resource development in economics and public policy. In Water Resource Development, ed. Stephen C. Smith, and Emery N. Castle, 82-135. Ames: Iowa State University Press.

Briscoe, John, Pablo Anguia Salas, and Peña T. Humberto. 1998. Managing water as an economic resource: Reflections on the Chilean experience. Paper No. 62, Environment Department Papers. Washington, DC: World Bank.

Brower, R. 2008. The potential role of stated preference methods in the Water Framework Directive to assess disproportionate costs. Journal of Environmental Planning and Management 51: 597-614. 
Bruton, R., and Frank J. Convery. 1982. Land drainage policy in Ireland. Policy Research Series 4. Dublin, Ireland: Economic and Social Research Institute.

Carson, Richard. 2011. Contingent valuation: A comprehensive bibliography and history. Cheltenham, UK: Edward Edgar.

Ciriacy-Wantrup, Siegfried V. 1947. Capital returns from soil-conservation practices. Journal of Farm Economics 29: 1181-96.

Coase, Ronald H. 1960. The problem of social cost. Journal of Law and Economics 3 (October): 1-44. Convery, Frank J. 2011. Reflections-Energy efficiency literature for those in the policy process. Review of Environmental Economics and Policy 5 (1): 172-91.

Deaton, Angus. 2009. Instruments of development: Randomisation in the tropics, the search for the elusive keys to economic development. Research Program in Development Studies, Center for Health and Wellbeing, Princeton University. http://www.princeton.edu/ deaton/downloads/Instruments_of_ Development.pdf.

Duflo, Esther, and Michael Kremer. 2003. Use of randomisation in the evaluation of development effectiveness. World Bank Operations Evaluation Department Conference on Evaluation of Development Effectiveness. July 15-16. http://economics.mit.edu/files/765.

European Commission. 2002. Guidance document No. 1. Economics and the environment-The implementation challenge of the Water Framework Directive: Luxembourg.

Gazmuri, Renato S. 1992. Chilean water policy experience. Paper presented at the Ninth Annual Irrigation and Drainage Seminar, December 9, World Bank, Washington DC.

Grafton, R. G., G. D. Libecap, E. C. Edwards, R. J. O’Brien, and C. Landry. 2011. A comparative assessment of water markets: Insights from the Murray-Darling basin of Australia and the Western US. Working paper No. 8/2011, International Centre for Economic Research, Turin and Prague. http://www.icer.it/docs/wp2011/ ICERwp08-11.pdf.

Gray, Brian E. 2008. The market and the community: Lessons from California's drought water bank.
West-Northwest Journal of Environmental Law and Policy 41 (1): 41-104.

Griffin, Ronald C. 2012. The origins and ideals of water resource economics in the U.S.

Annual Review of Resource Economics 4: 353-377. doi:10.1146/annurev-resource-110811-114517.

Hanemann, Michael J. 1984. Welfare evaluations in contingent valuation experiments with discrete responses. American Journal of Agricultural Economics 66 (3): 332-41.

1994. Valuing the environment through contingent valuation. Journal of Economic Perspectives 8 (4): 19-43.

1997. Prices and rate structures. In Urban water demand management and planning, ed. D. D. Baumann, J. Boland, and W. M. Hanemann, 137-79. New York: McGraw-Hill.

Hanemann, M., D. Lambe, and D. Farber. 2012.

Legal analysis of barriers to adaptation for

California's water sector. California Energy

Commission, Public Interest Energy Research (PIER) Program White Paper, Berkeley: University of California. CEC-500-2012-019http://www.law. berkeley.edu/files/ccelp/CEC(1).pdf.

Hanley, N., R. Wright, and B. Alvarez-Farizo. 2006. Estimating the economic value of improvements in river ecology using choice experiments: An application to the water framework directive. Journal of Environmental Management 78: 183-93.

Haveman, Robert H. 1972. The economic performance of public investments: An ex post evaluation of water resource investments. Baltimore: Johns Hopkins Press for Resources for the Future.

Hearne, Robert R., and K. William Easter. 1995. Water allocation and water markets-An analysis of gains from trade in Chile. World Bank Technical Paper No. 315, Washington, DC.

Howitt, Richard E. 1994. Empirical analysis of water market institutions: The 1991 California water market. Resource and Energy Economics 16: 357-71.

Israel Climate Change Information Center. 2011. Israel adaptations to climate change: Policy recommendations-ICCIC 2nd report. Ministry of Environmental Protection and University of Haifa. http://old.sviva.gov.il/bin/en.jsp?enPage=e_Blank 
Page\&enDisplay $=$ view\&enDispWhat $=$ Object $\&$ enDispWho=News $\wedge$ 15624\&enZone $=$ e_news.

Kahneman, D., and J. L. Knetsch. 1992. Valuing public goods: The purchase of moral satisfaction. Journal of Environmental Economics and Management 22: 57-70.

Kneese, Allen V. 2000. Whatever happened to benefit-cost analysis? Water Resources Update 116 (March): 58-61.

Kneese, Allen V., and Blair T. Bower. 1968. Managing water quality. Baltimore: Johns Hopkins Press for Resources for the Future.

Olmstead, Sheila M. 2010a. The economics of water quality. Review of Environmental Economics and Policy 4 (1): 44-62.

-2010b. The economics of managing scarce water resources. Review of Environmental Economics and Policy 4 (2): 179-98.

Olmstead, Sheila M., W. Michael Hanemann, and Robert N. Stavins. 2005. Do consumers react to the shape of supply? Water demand under heterogeneous price structures. Discussion paper 05-29. Washington, DC: Resources for the Future. Olmstead, Sheila, and Robert N. Stavins. 2009. Comparing price and nonprice approaches to urban water conservation. Water Resources Research 45, W04301, 10 PP doi:10.1029/2008WR007227.

Organization for Economic Co-operation and Development (OECD). 2010. Pricing water resources and water sanitation services, Paris, France.

2012. Meeting the water reform challenge, Paris, France.
Pigou, A. C. 1952. The economics of welfare, 4th ed. London: Macmillan.

Pigram, John J. 1993. Property rights and water markets in Australia: An evolutionary process toward institutional reform. Water Resources Research 29 (4): 1313-19.

Prüss-Üstün, A., R. Bos, F. Gore, and J. Bartram. 2008. Safer water, better health: Costs, benefits and sustainability of interventions to protect and promote health. Geneva, Switzerland: World Health Organization.

Thobani, Mateen. 1995. Tradable property rights to water-How to improve water use and resolve water conflicts. FPD Note 34, Public Policy for the Private Sector series, World Bank. http://rru.worldbank.org/documents/publicpolicyjournal/ 034thoban.pdf.

Waye, Vicki, and Christina Son. 2010. Regulating the Australian water market. Journal of Environmental Law 22 (3): 431-59.

Whittington, Dale, Donald T. Lauria, Albert M. Wright, Kyeongae Choe, Jeffrey A. Hughes, and Venkateswarlu Swarna. 1993. Household demand for improved sanitation services in Kumasi, Ghana: A contingent valuation study. Water Resources Research 29: 1539-60.

World Water Assessment Program. 2009. The United Nations World Water Development Report 3: Water in a changing world. Paris, France: UNESCO. 